\title{
第53回 全日本鍼炎学会学術大会（千葉）
}

\section{シンポジウム III}

\section{「脳活動と鍼炎」}

梅田雅宏 ${ }^{1)}$ 、下山一郎 ${ }^{2)}$ 、木村友昭 ${ }^{3)}$ 、田中忠蔵 ${ }^{4)}$

1）明治鍼尒大学医療情報学

2）千葉大学フロンティアメディカル工学研究開発センター脳機能計測解析研究部門

3）国立大学法人 筑波技術短期大学

4）明治鍼尒大学脳神経外科

\section{要 旨}

中枢神経を介した鍼炎の治療効果を調べることを目的に、鍼炎刺激により生じる中枢 神経の局所活動を人の脳で調べる方法について紹介する。鍼炎刺激は感覚刺激として入 力され、中枢神経で処理される。この時の脳の応答を調べる方法として脳波が広く用い られてきた。しかし、脳波を利用した方法は中枢神経の活動場所を特定する点で問題が あった。この問題を解決するために、神経の電気活動に伴って発生する微弱な磁場を空 間的に並べられた受信コイルで捉え、磁場発生源の位置を推定するMEG法、この神経活 動に伴い変化する血液中のオキシへモグロビンとデオキシへモグロビンのそれぞれを、 近赤外光の吸収スペクトルの差から分離して捉える赤外分光法、さらに、血液中に生じ たデオキシへモグロビンが持つ磁化率変化を信号強度に反映させた脳機能核磁気共鳴画 像 (fMRI) 法を取り上げ、中枢神経における局所活動について調べる方法を紹介する。

キーワード：脳、中枢神経、機能、鍼尒、近赤外分光法、MEG、fMRI

\section{I 。はじめに}

近年脳の研究は非常に速い速度で進歩しており、 同時に中枢神経の活動が身体に与える様々な影響 が議論されるようになってきた。このような状況 のなかで、鍼众刺激の中枢神経への影響を調べる ことはますます重要となっている。一方、「感じ る」という主観的な情報は中枢神経の様々な活動 を捉える技術の進歩で、客観的情報に変わりつつ ある。今回は、鍼尒が中枢神経に与える影響を調 べるための最新技術を紹介すると同時に、どのよ
うな応答が捉えられているのかの現状を知り、今 後の研究活動の指針になればと考えた。

今回は最近の脳研究の中から、神経活動の主体 である電流を、その電流の作る磁場の観測により 捉える脳磁図 (magnetoencephalo-graphy, MEG)、 その神経活動を支える脳血流と血液が運搬する酸 素量を調べることのできる近赤外スペクトル分光 法、さらにこれらの血液の酸素飽和度を反映する 脳機能磁気共鳴画像法 (functional magnetic resonance imaging, fMRI) を取り上げた。

（代表連絡先）梅田雅宏 干629-0392 京都府船井郡日吉町 明治銊尒大学 医療情報学 


\section{II．近赤外スペクトル分光法}

千葉大学フロンティアメディカル工学研究開発セ ンター 脳機能計測解析研究部門

下山一郎

\section{1. 目的}

鍼治療における大脳入カニズム学解析する目 的にて、光トポグラフィー®によるつぼの役割を 健常人の合谷刺激をもちいた大脳へモグロビン酸 素飽和度の变化にて観察した。

\section{2. 方法}

健康なボランティア9名（21-56歳）から、光

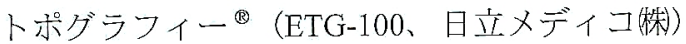
頭部左右半球の第一次体性感覚中心に $6 \times 6 \mathrm{~cm}$ 領域に装着して、左右それぞれ12部位から、酸 化型へモグロビンの増加分について検討した。被 験者には合谷鍼刺激中の近赤外線による脳血流測 定と説明しインフォームドコンセトを得た。ステ ンレス鍼（No. $2 \times 40 \mathrm{~mm} ， \mathrm{~J}$ type セイリン侏）を もちいて、左手合谷に2箇所選択し（1 cm離れた 遠位点A、近位点B）刺激した。安静閉眼でイス
座位にて、まず遠位点 $\mathrm{A}$ の検討：安静 30 秒・鍼 管あて 30 秒・切皮してのまま 30 秒・筋膜手前ま で刺入乙置銊 30 秒・筋膜通過さ好雀啄 30 秒・そ の位置で置鍼 30 秒・抜銊を無声・無合図にて試 行。2-3分休息の後、近位点 $\mathrm{B}$ の検討を遠位点 Aと同じ手順で記録した。

\section{3. 結果}

7例とも左大脳で近位点 $\mathrm{B}$ 合谷刺激の方が遠位 点 $\mathrm{A}$ 合谷刺激より血流が増加した。2例では遠位 点A合谷で血流増加を示した。全例で両半球で血 流増加が観察された。

7 例中左大脳半球で徐々に血流増加がみられ、 雀豚で最高になる例、樑く刺入で最高になる例、 切皮で最高になる例、雀豚後に最高になる例がタ られた。この7例の右大脳半球でも徐々に血流増 がみられ、2例は雀豚で最高に達し（図 1)、3例 は深く刺入操作で著明に血流増加がみられた。

2例からは、はじめに試行した遠位点A合谷の 方が血流増加がみられ、2例とも雀豚または雀豚 後に血流増加が左右両半球あり、右大脳半球で大

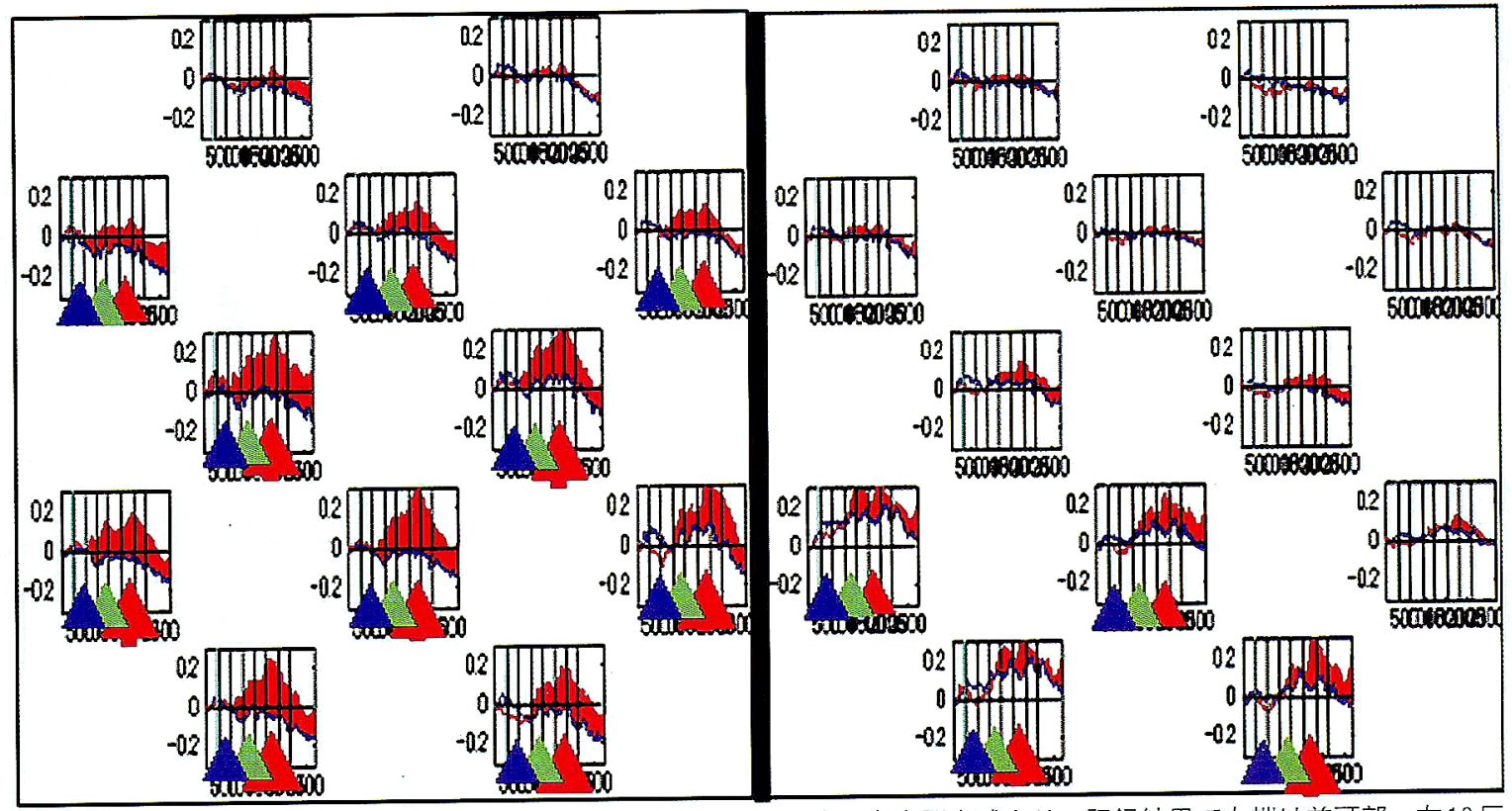

図 1：左合谷における経過と血流変化経過の一例。右半分の12 反応は左大脳半球よりの記録結果で左端は前頭部、左 12 反 応は右大脳半球よりの結果で右端が前頭部、赤いエリアが血流変化の堌加を示す（近位合谷刺激から遠位合谷刺激 を引き算による観察)。横軸(経過時間でひとコマ30秒 縦軸は組織酸素飽和度の相対值。青矢印は鍼管設置時、 緑矢印は深く刺入中、赤矢印は雀啄時に相当する。 
きく増加した。

\section{4. 考察}

光トポグラフィー ${ }^{\circledR}$ は、近年世界に先駆け日本 から製品化された画期的な近赤外スペクトル分光 法であり、拘束性・侵襲性などの優れた非侵襲的 脳機能計測法である。近赤外線は頭皮表面から頭

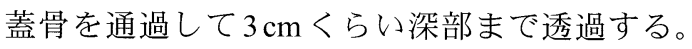
酸化型へモグロビンは鮮紅色で還元型へモグロビ ンは暗赤色という吸光特性を利用し、780 と 830 $\mathrm{nm}$ 波長の近赤外線を照射してその反射（吸光係 数）を計測する。神経活動により産生される炭酸 ガス増加が組織の血管拡張をおこし酸化型へモグ ロビンの供給が増加する。すなわち組織の吸光係 数の割合から、酸化型と還元型へモグロビンの割 合の変化を推測し、酸素飽和度が推測できる。酸 素飽和度が、連続した時間経過の中で変化すれば、 活動している大脳組織の活動の痕跡を追跡できる。 統一された異差の明瞭な 2 課題を短時間の間に試 行すれば、これにより変化する酸素飽和度は課題
間の差と考えられる。この前提のもとに、血流変 化に数秒要す事実と、安定するまでのゆとりを考 慮し、ひとつの課題を 30 秒とした。結果からは、 左手は右大脳の第一次体性感覚野で処理されてい るという神経結合からの解剖学的事実では説明不 可能で、正中神経電気刺激により起こる早期の反 応とは異なったメカニズムを考えなくてはならな い。解剖学的にも左右の大脳半球を連絡する脳梁・ 前後の交連線維、帯状回を代表とする前後を連絡 する線維などの皮質内連合線維の存在からは、つ ぼ刺激は、第一次体性感覚を利用したさらに時間 かけた高次の処理をしているメカニズムと推測し た。第一次体性感覚野に至るまでに、図 2 にる ように、受容器から発生した感覚は脳幹の意識の 助けにより、中間皮質での情動により修飾され、 大脳連合野の認知処理後に感覚となる。情動・認 知を考慮すれば広範な大脳賦活、経験経歴などの 個人差は当然と考える。遠位つぼA でも近位つぼ Bでも得気を得られた事実、また鍼管設置だけで も血流増加の結果、切皮だけでも血流増加の見ら

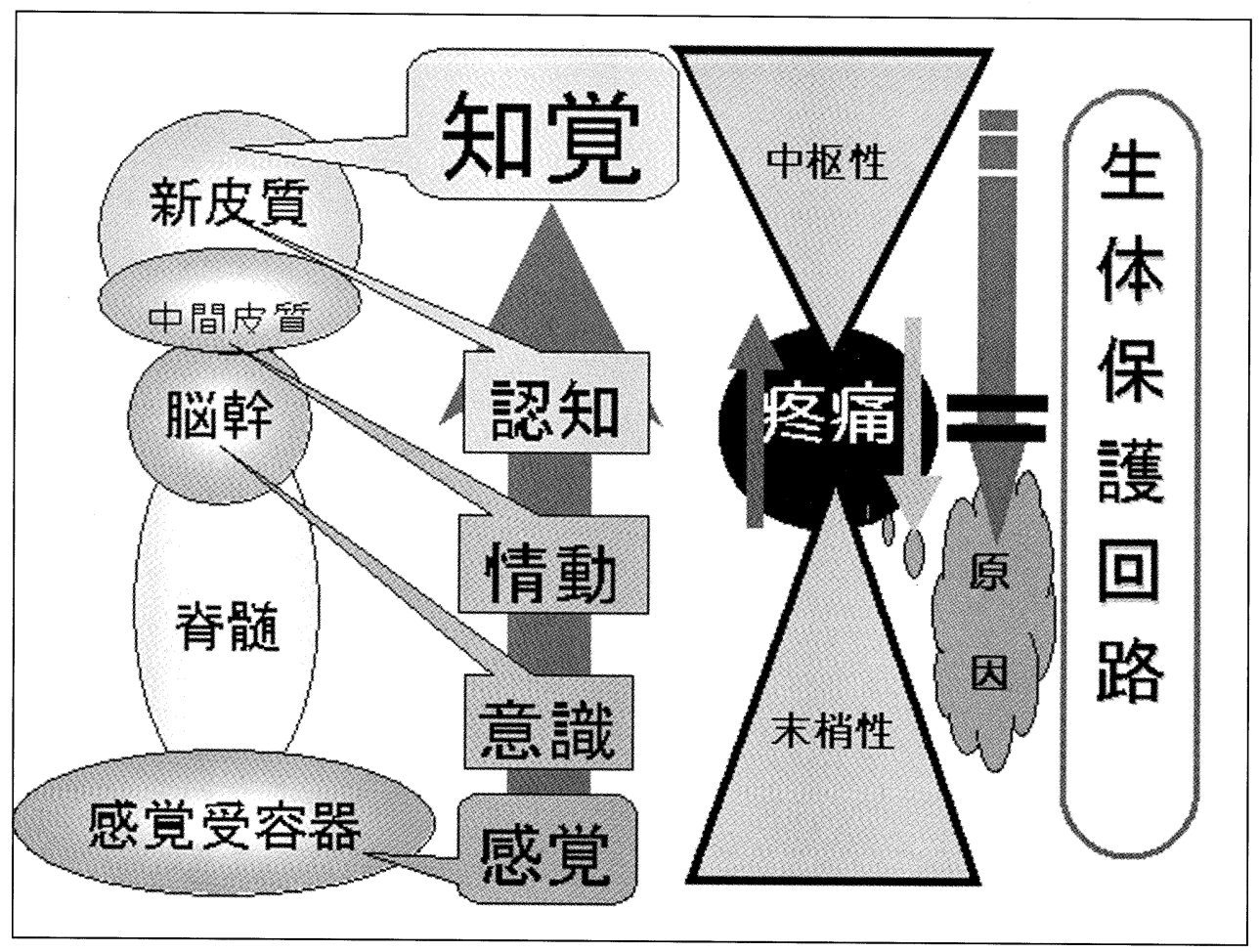

図 2：いたみの認知メカニズム 
れた被験者、雀豚後に血流増加の見られた被験者、 これらは日常の臨床鍼治療からは当然の事実と推 測する。今回これらの事実を客観的半定量的デー 夕として解析し、事実のメカニズム解明の手助け になれば幸いである。古来東洋医学は正常を治療 するのではなく、主訴を元に戻すことを実践して 来た事実を考えると、健康ボランティアゆえの結 果とも結論できる。他モダリテイーの複合的計測 から推測することが望ましく、主訴を持った症例 の今後の詳細な検討が待たれる。

\section{5. 結語}

（1）合谷は皮膚水平方向にも鉛直方向にも点では ない。

（2）個人差（経験歴）の重要性が疑われた。

（3）"プラセボー効果"の重要性が疑われた。

（4）"いたみ"は生体の安全保護回路・火災報知器 という認識を患者さんにも理解してもらい、 痛みの原因を追究しその原因除去に役立たせ たい。

\section{謝 辞}

研究遂行にあたり千葉地方会の金井正博、木南 真紀子、酒井茂一、相野谷真貴子、研究班員、関 東鍼尒専門学校の学生さん達、日立メディコ株式 会社、千葉大医学研究院神経情報統合生理学博士 課程の笠置泰史、吉田晋に感謝します。

\section{III. 脳磁図 (MEG) によるヒト脳機能研究} 一体性感覚誘発脳磁界 (SEFs) を中心に一 国立大学法人 筑波技術短期大学 木村友昭

\section{1.はじめに}

近年、ヒト脳機能を測定する手法として脳磁図 (magnetoencephalography, MEG) が注目されてい る。ここでは、MEGの原理と特徵、本法を用い て得られた臨床神経学的知見を述べ、さらに鍼众 研究領域への適用例について述べる。

\section{MEGとは}

（1）皮質内電気現象と MEG

大脳皮質第 III 層から V 層には、皮質表面に垂
直方向に規則正しく配列された錐体細胞が多数存 在している。この錐体細胞の尖頭樹状突起に対し、 視床や他の皮質領野からの入力が認められている。 たとえば、視床からの上行線維は、皮質第 IV 層 の錐体細胞尖頭樹状突起の深層側にシナプスを形 成することが知られているが、このシナプスでの 情報伝達の際に生じるシナプス後電位は錐体細胞 尖頭樹状突起内で深層から浅層に向かう上向きの 細胞内電流を生じる。

このような細胞内電流によって"右ねじの法則" にしたがって生じる磁界を測定する方法が MEG である。一方、細胞内電流の発生によって生じる 細胞外帰還電流（細胞内電流とは逆の向きを持つ） を電位差として検出する方法がよく知られた脳波 (electroencephalography, EEG) である。このよう に、MEG とEEG は同一の現象を異なる局面から 観測したものといえるが、後発の MEG 計測が注 目されている最大の理由は、得られる神経活動の 発生源（信号源）を推定する上での優位性による。 すなわち、頭蓋は導電率の大きく異なる骨、各種 軟部組織、脳脊髄液などが複雑に入り組んだ構造 になっているため、EEGでは生じた電流が頭皮 上で検出されるまでに大きく歪められ、信号源の 推定計算が極めて複雑になる。これに対し、磁界 は生体の組織の影響をほぼ無視できるため、信号 源推定計算処理が比較的容易なのである。ここで 述べている信号源とは、数百〜数千以上の細胞内 電流の時間・空間的加重によって得られた、いわ ば合成電流であり、これを等価電流双極子 (equivalent current dipole, ECD) と呼ぶこともあ る。

(2) 脳磁計

脳磁界は地磁気の $1 \sim 10$ 億分の 1 のきわめて微 弱な磁界であるため、超伝導量子干渉素子 (superconductive quantum interference device, SQUID）をセンサー部に使用した脳磁計を環境 磁気ノイズの混入を防ぐための磁気シールドルー ム内に設置して測定する。同時に測定できる脳磁 界信号の数は 1990 年代には数〜数十であったが、 近年のシステムでは百〜数百にまで増え、脳を覆 うほぼ全頭の磁界信号を同時に記録できるように 


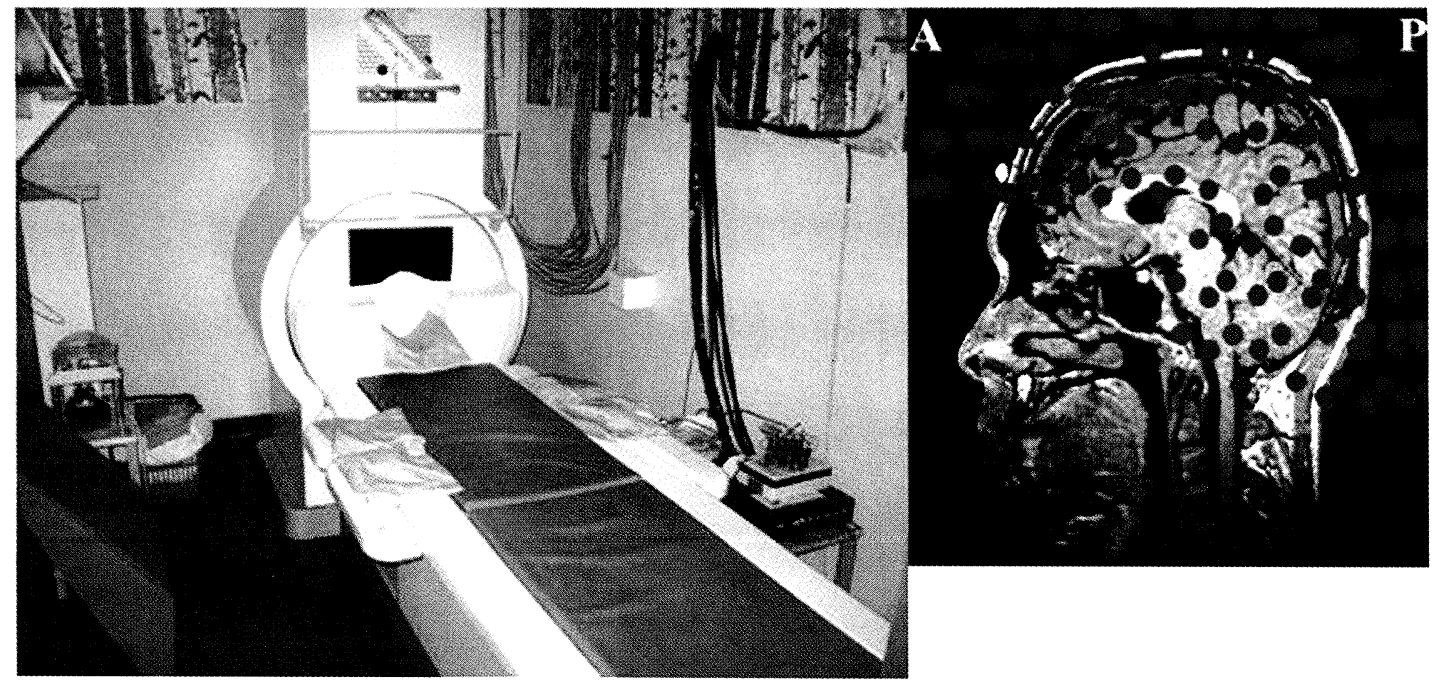

図3 全頭型脳磁計（左）とセンサーレイアウト（右:青点）

表1 自発と誘発MEGの分類

\section{A) 自発MEG \\ a. $\alpha$ 波 \\ b. てんかん波 \\ B) 誘発MEG
a. 感覚誘発MEG
(各種感覚刺激 (体性感賞、視覚、聴賞など)による脳活動)
b. 運動関連MEG
（各種随意運動等にともなう脳活動）
c. 事象関連MEG \\ （特定の精神活動を伴う課題(task)を遂行する際の脳活動)}

なった（図3）。これらの各センサーにより、頭 皮上のどの部位で磁束が湧き出しているか、ある いは吸い込まれているかを測定し、その情報をも とに信号源位置・向き・強度を算出し、その結果 をMRI画像に重ね合わせることにより、信号源 の解剖学的位置を判断する。

一般に、十分な信号強度の単一信号源推定結果は ミリメートル単位の精度をもち、データ収録速度 もミリ秒単位である。時間・空間分解能の高さが 脳磁界計測の最大の特長であるといえる。

\section{MEGの実際}

（1）脳磁界の分類

脳磁界は測定方法、刺激の種類によって、表 1 に 示すように分類可能である。アルファ活動やてん
かん発作波など、自然発生的な脳磁界を自発脳磁 界と呼び、特にてんかん焦点の位置測定は臨床上 有用である。一方、各種感覚刺激や運動、あるい は課題遂行など特定の条件（イベント）によって 一定の時間（潜時）を経て発生する脳磁界を誘発 脳磁界と呼ぶ。通常、誘発脳磁界は自発脳磁界に 比して 10〜100 分の 1 程度の弱い信号であるため、 混在する自発脳磁界の影響を最小限にする目的で、 同一条件のデー夕を複数回測定し、イベント発生 時点を起点として加算平均処理を行う。以下、鍼 众研究と関連が深いと考えられる体性感覚誘発脳 磁界の概要と近年の研究によって得られた知見の 一部を紹介する。

（2）体性感覚誘発脳磁界

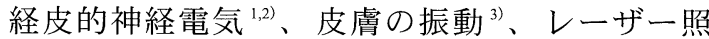
射な゙この各種体性感覚刺激によって誘発される 一連の脳磁界を体性感覚誘発脳磁界 (somatosensory evoked magnetic fields, SEFs) と 呼ぶ。SEFsの出現パターンは刺激提示後約 $60 \mathrm{~ms}$ までの短潜時成分と、それ以降の長潜時成分で異 なっている。

\section{1）短潜時成分 $(<60 \mathrm{~ms})$}

最も早期に出現する磁界は上肢神経の電気刺激 では潜時約 $20 \mathrm{~ms}^{1)}$ 、下肢では約 $37 \mathrm{~ms}^{2)}$ で出現し、 その信号源は刺激対側の中心溝後壁（第一次体性 
感覚野上) に推定される。また、刺激部位と信号 源位置はペンフィールドの地図にほぼ一致する。 すなわち、上肢指刺激では中心溝ほぼ中央部から 下方向に小指〜母指刺激の信号源を認め ${ }^{5)}$ 、下肢 神経刺激では頭頂部に信号源が定位される ${ }^{2)}$ 。こ の成分以降、潜時約 $60 \mathrm{~ms}$ までに数個の磁界成分 が観察されるが、これらの成分は最初期成分とほ ぼ同様の位置に推定されることが多く、未梢から の感覚情報の初期処理過程を反映するものと考え られる。さらに近年では、高デー夕収録速度・高 加算回数によるデー夕を分析することにより、皮 質錐体細胞内電流のみでなく、その近傍に位置す る抑制性介在二ューロンの活動と考えられる信 号 $^{6}$ や、錐体細胞群の興奮の水平繊維を介した伝 播を反映していると考えられる結果 〕も報告され、 MEGの高時間・空間分解能を生かした貴重な知見 であると考えている。

\section{2）長潜時成分（>60 ms）}

SEFs では、短潜時成分に引き続いて潜時 $60 \mathrm{~ms}$ 以降にも誘発磁場成分が観察できる。一般に、こ

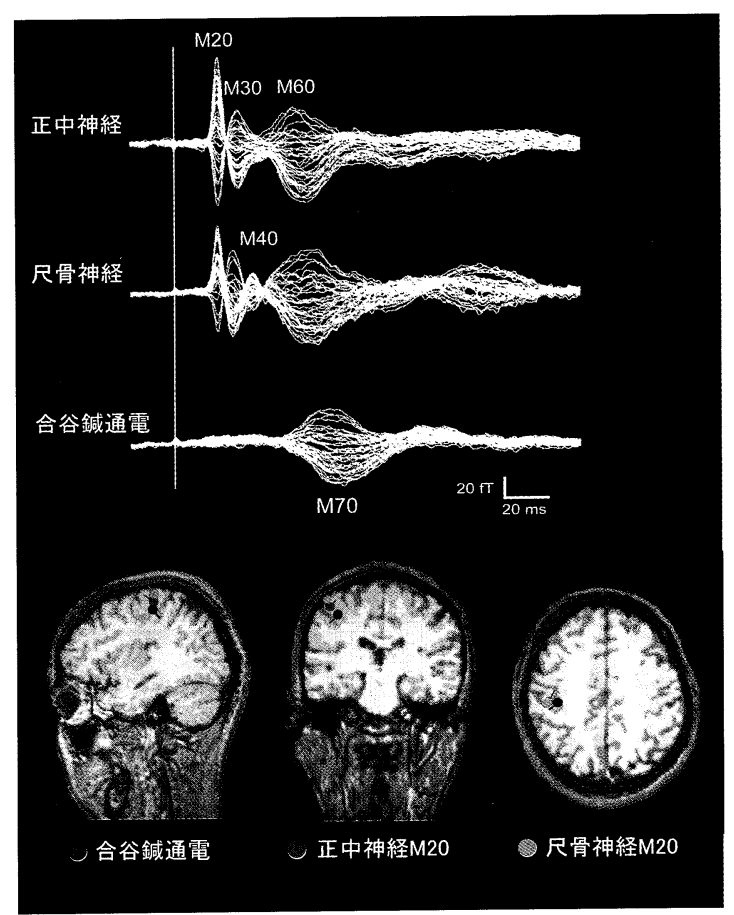

図4 正中・尺骨神経電気刺激と合谷鍼通電刺激による SEFs 波形と初期成分信号源位置
の潜時帯では感覚情報処理が複数の皮質領域で同 時に進行すると考えられ、実際に各センサーから 得られる磁場パターンも複雑になる。

複数信号源の同時推定については、これまでに いくつかの手法が提案され、応用されている が ${ }^{899} 、$ MEG 信号だけで完全解を求めることは理 論上不可能であり、いかなる手法も一定の仮定を 置く必要があるため、仮定の選択と結果の解釈に は慎重さが要求される。これまでの検討結果 ${ }^{8,9}$ では、第一次体性感覚野に加え、第二次体性感覚 野、体性感覚連合野、島、帯状回なぞ、体性感覚 情報処理と関連が深いと考えられている部位が長 潜時 SEFs の信号源として報告されている。

\section{4. 鍼炎研究とSEFS}

筆者らは、経穴への鍼通電刺激によるSEFs が 通常の経皮的神経刺激のそれとどのように異なる かについて検討を行つているが ${ }^{10}$ 、鍼尒研究にお ける MEGの応用例として、その概要を紹介する。

成人男性 8 名を対象に、右合谷穴への絶縁鍼に よる通電刺激を与え、左右体性感覚野上に配置し た74チャンネル脳磁計により脳磁界を計測した。 また、正中神経および尺骨神経の経皮的電気刺激 によるSEFs も測定し、得られた信号源を比較検 討した。その結果、合谷穴刺激では、正中神経・ 尺骨刺激による SEFs と大きく異なり、潜時約 20〜 60 ms までの皮質初期成分（M20，M30，M40, M60) が観察されず、潜時約 $70 \mathrm{~ms}$ の成分 (M70) のみが高い再現性で観察された(図4上)。合谷穴 刺激による M70の信号源は、正中神経・尺骨神 経刺激 SEFs の M20、M60 と比較して内下方に位 置していた(図4下)。これまでの諸家の検討によ り、正中・尺骨神経刺激 SEFs の M 20 は第一次体 性感覚野の中でも中心溝の後壁をなす部位、すな わち、ブロードマンの area $3 \mathrm{~b}$ に起源をもつこと が明らかとなっている ${ }^{0}$ 。この部は主として皮膚 からの感覚情報を受ける部位とされており、絶縁 鍼による合谷刺激SEFsにおいてM20が観察され なかったことは、この刺激が主として深部組織へ の入力になっているであろうことと符合している と考えられた。M70の信号源としては、筋求心 線維の入力を受け、area $3 \mathrm{~b}$ の深部に位置する area 
$3 \mathrm{a}$ 、関節等の深部知覚の処理と関連するとされ、 中心後溝の前壁に存在する area 2、あるいはその 両方の合成電位である可能性が考えられた。なお、 刺激する神経をすべて同一とするため、（1）短母 指外転筋の運動点 (魚際穴近傍) への絶縁鍼刺激、 (2) 示指への知覚神経刺激、（3) 正中神経束刺激を それぞれ行った際のSEFsについても検討してい るが ${ }^{11)}$ 、上述の合谷穴刺激実験と基本的に同様の 結果を得た。

これらの結果より、鍼による深部組織への通電 刺激は、経皮的な神経刺激とは初期皮質投射の段 階で明らかに異なることが明らかとなったが、今 後は初期応答に引き続いて起こる活動の部位、及 び時間について検討を進めたいと考えている。ま た、鍼刺激に伴う "ひびき感覚" の有無と誘発脳 磁界成分との関係についても検討すべきであろう。 しかしながら、MEGにおける長潜時帯の複数信 号源の推定には一定の限界があり、結果の慎重な 解釈が必要であることはすでに述べた通りである。 推定手法のさらなる進歩が望まれる一方、他の機 能画像手法 (fMRI・光トポグラフィ・PETなど) との結果の比較検討により、手法上の長所・短所 を補い合いながら結論を目指す研究スタイルが今 後重要になると考えている。

\section{III. ファンクショナルMRIによる鍼炎の検討}

明治鍼尒大学 脳神経外科、医療情報学、

MRセンター

田中忠蔵、福永雅喜、染谷芳明 中越明日香、森 勇樹、青木伊知男 梅田雅宏、樋口敏宏

\section{1. $M R \mid$ ¿ $f M R \mid$}

磁気共鳴画像法は、一定の磁場におかれた人体、 体の組織中にある水に含まれる水素原子核が特定 の周波数の電磁波に共鳴することから、この共鳴 信号を画像化する方法である。現在、広く用いら れている $1.5 \mathrm{~T}$ （テスラ）の MRIは、約 $64 \mathrm{MHz}$ の FM電波領域で共鳴する。この程度の磁場と電磁 波では、今のところ人体に害をおよぼす証拠は見 つかっていない。安全に、繰り返しての検査が可
能とされていて、ごく一般の臨床診断に用いられ るようになつている。

ファンクショナル MRI（fMRI）は、脳の一部 に神経活動が生じると、その部位の脳組織の血液 循環は著しく増加する（30-50\%）が代謝の増加 はわずか $(-5 \%)$ であるので、これらのアンバラ ンスから、その部位のMRIの信号の強さが、安 静時の活動していない場合の信号に比べて低下す るので、局所脳活動部位が描出できる、とする方 法である。米国べル研究所の小川誠二先生がその 原理を見いだし、日本人にはなじみのある検査手 法と言える。実際のfMRIは、上述したような安 全簡便な検査方法として、現在さまざまな脳研究 に用いられている。米国では、代替医療の積極的 な再評価の機運が生じ、EBMを目指すさまざま な試みが行われ、研究費の投入も続いている。そ の一端として、鍼尒の科学的評価の方法として fMRIを用いた研究が数多く行われるようになつ てきている。

臨床用 MRIの磁場強度については従来 1.5 テス ラまでが認められてきたが、最近では 3 テスラ装 置も保険診療の認可が得られるようになつた。一 方、脳機能研究では、すでに3テスラ以上の装置 が米国を中心に開発され広まっており、磁場強度 7、8テスラ装置が作られている。我が国にも、 新潟大学脳研に7テスラ装置が導入された。

\section{2. fMRIによる鍼炎研究の現状}

鍼众界で話題になっているように、米国 NIH （National Institute of Health）を中心に代替医療、 伝統医療を積極的に評価する試みが行われている。 鍼众に関する研究についても同様であり、研究資 金がこの分野に積極的に投下されはじめてい $3^{12,13)}$ 。従来からfMRI 研究手法に用いている研 究施設では、鍼尒を対象にした検討も報告されて いる。ただしその結果については、いまだコンセ ンサスが得られているとは言い難い。Choらが報 告した眼の疾患を治療する経穴への刺激の例が極 めて特徵的である ${ }^{14)}$ 。眼の関連経穴に中国鍼を用 い、Deqi刺激を持続的に行った画像と行わなかっ た画像から、鍼尒刺激で後頭葉の視覚中枢に局所 脳賦活が認められた、との報告が米国の有名雑誌 
であるProc Natl Acad Sci誌に掲載された。これ に対していくつかの追試験が行われ、同様の結果 が得られたとする報告と、得られなかったとの報 告が行われている。筆者らが行つた fMRIの結果 では、視覚中枢に脳賦活は認められなかつた。た だしこの場合、「ひびき」を数十秒の間確実に繰 り返して持続させることはできなかった。統計処 理を中心とした実験研究の難しさが現れた研究報 告である。

もう一つ別の問題が、fMRIによる銊刺激の研 究にみられる。通常の fMRIでは、例えば右の手 指を動かすと左の一次運動中枢に運動時に同期し た信号の増強が認められる。問題となるのは、鍼 刺激によって、刺激に同期した信号の増強ではな く、減弱が視床下部などの部位に見られるとする 報告である。全く逆の応答を示すこの信号減少は、 今のところ視覚刺激に伴う乳児の後頭葉に観察さ れるとの報告が見られるとのコンセンサスが得ら れているようであるが、鍼众刺激に伴う変化には、 いまだ合理的な説明がなされていない。筆者らの 鍼众刺激の検討では、いずれも信号が逆転する有 意な現象を見いだしていない。

以上のように、おもに fMRIによる鍼刺激の検 討では、鍼尒刺激に特有ではないかとする論文の 結論については、いまだ充分に証拠のある研究成 果であると言い難い現状である。方法論としての fMRIは、装置さえあれば簡単ではあるものの、 やはり充分な装置性能評価を行うことが前提とな る。さらには、fMRIの結果は、あくまでも統計 処理上のデータであり、MRIのように実際の解 剖学的な構造が画像化されているものとは異なつ ている。fMRIでは、従来用いられてきた他の方 法論の結果と比較して、合理的な結果は尊重でき るものの、全く新しい結果が得られ、他の方法に よる裏付けがない場合、その取り扱いは慎重にな る必要があるようである。

\section{3. fMRIによる鍼负刺激の検討}

人体用 3 テスラ装置を用いて鍼通電刺激と众刺 激を fMRIで検討した例を紹介する。いずれも装 置はGE社製 Signa LXに通常のヘッドコイルを用 いた。倫理委員会の規定に従って、被験者全員に
口頭と文書による検査に対する説明を行い、同意 を得た。

（1）鍼通電刺激について：通電刺激は、右手合谷 に鍼を留置した後通電し、痛刺激を感じる閾值の $1 / 2$ の電流を使用した。従って、この刺激で被験 者に痛みは生じなかった。5名を対象に行い、3D 画像、通常のT2強調画像を撮影した。fMRIは、 通電刺激 40 秒間と安静 40 秒間を交互に 5 回くり 返した。画像と統計処理にはSPM99ソフトウエ アを用いた。この際、測定中に頭部が動くと写真 のブレのような現象が生じるために $1 / 2$ ピクセル 以上の動きを生じたものは結果に採用しなかった。 また、動きがこの範囲以内のデー夕は動き補正を 行った上で画像処理した。結果は、グループ全体 の一群とするグループ解析を行い、有意水準 $1 \%$ 以下を $\mathrm{T} 1$ 強調画像に重礼て表示した（図5）。対

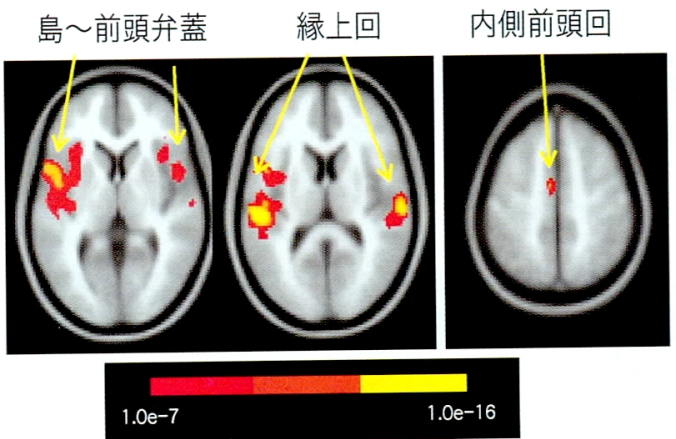

図 5 合谷鍼通電刺激の脳機能画像 鍼通電刺激時の代表的脳賦活領域を示している。 縁上回 (SMG) 加島 (INS)、内側前頭回 (MFG) に 脳賦活が認められた。

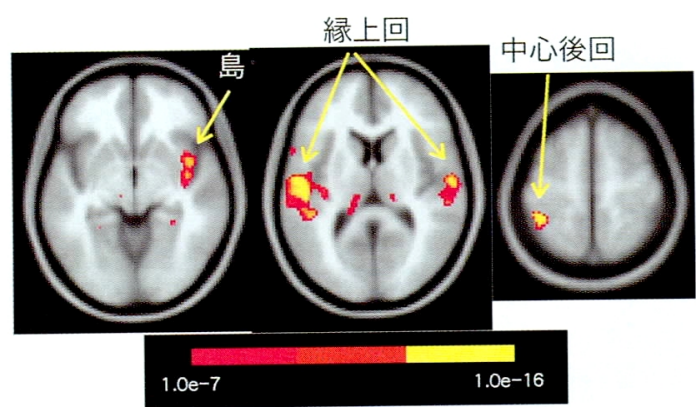

図6 合谷擦過刺激時の脳機能画像 右合谷擦過刺激時の代表的脳賦活領域を示している。 左中心後回 (PCG)、緑上回 (MFG)、右島 (INS) に 賦活領域が認められた。 
照として、全く同じ条件で、同じ合谷をスポンジ 擦過した感覚刺激を行った（図6）。

痛覚閾值以下、つまり痛みを感じない程度の合 谷の通電刺激では、一次感覚野に賦活領域が認め られなかった。一方、スポンジ刺激では、一次感 覚野に顕著な賦活領域を認めることができる。両 刺激の共通の所見として、シルビウス裂内にある 島葉に位置する二次感覚野に賦活領域が認められ た。このように触覚刺激と同じ傾向を示す一方、 通電刺激のみで認められる賦活領域は、両側の大 脳半球が接している大脳縦裂の内側面に観察され た。この領域は補足運動野として知られていて、 ここで賦活された位置は、他の研究から痛覚刺激 において賦活され、痛みに関係があるとされてい る部位であると考えることができた。痛みに関す る fMRIの報告から、この部位が痛みの受容に関 係していると推測される。この結果は、大変興味 深い。痛みを感じない刺激であるはずの通電刺激 が、痛みを感じる際に賦活される部位と同じ所を 賦活することは、鍼众刺激の脳内処理過程を考え
る一つの根拠を与える。

(2) 众刺激と温熱刺激の fMRI

众刺激の fMRIは、鍼刺激に比べてほとんど報 告されていない。fMRIの測定には、上述したよ うに刺激と安静を繰り返して行う必要があるため、 お众の刺激をこのパラダイムに合わせて施行しな ければならないので、本来のお众の持つ熱変化、 燃焼変化をとらえることが難しいためと考えられ る。そこで、筆者らは、温筒众を用い、これを燃 焼させて一定温度に到達するのを確認した後 60 秒間合谷におき、次の 60 秒間を休息するサイク ルを4回繰り返した。しかし、このパラダイムで は、fMRIで局所の脳賦活領域が認められなかつ た。おそらく、温筒众による刺激が少なかったた めと考えられた。そこで、温筒众の点火から消え るまでの時間を全て刺激として扱い、2荘連続し た刺激を行ったが、この刺激では、対側の前頭葉 （運動前野と前頭前野）に賦活領域が認められた (図 7)。この結果をパイプに $35^{\circ} \mathrm{C}$ の温水を通して 合谷に当てておこなった温熱刺激と比較すると、
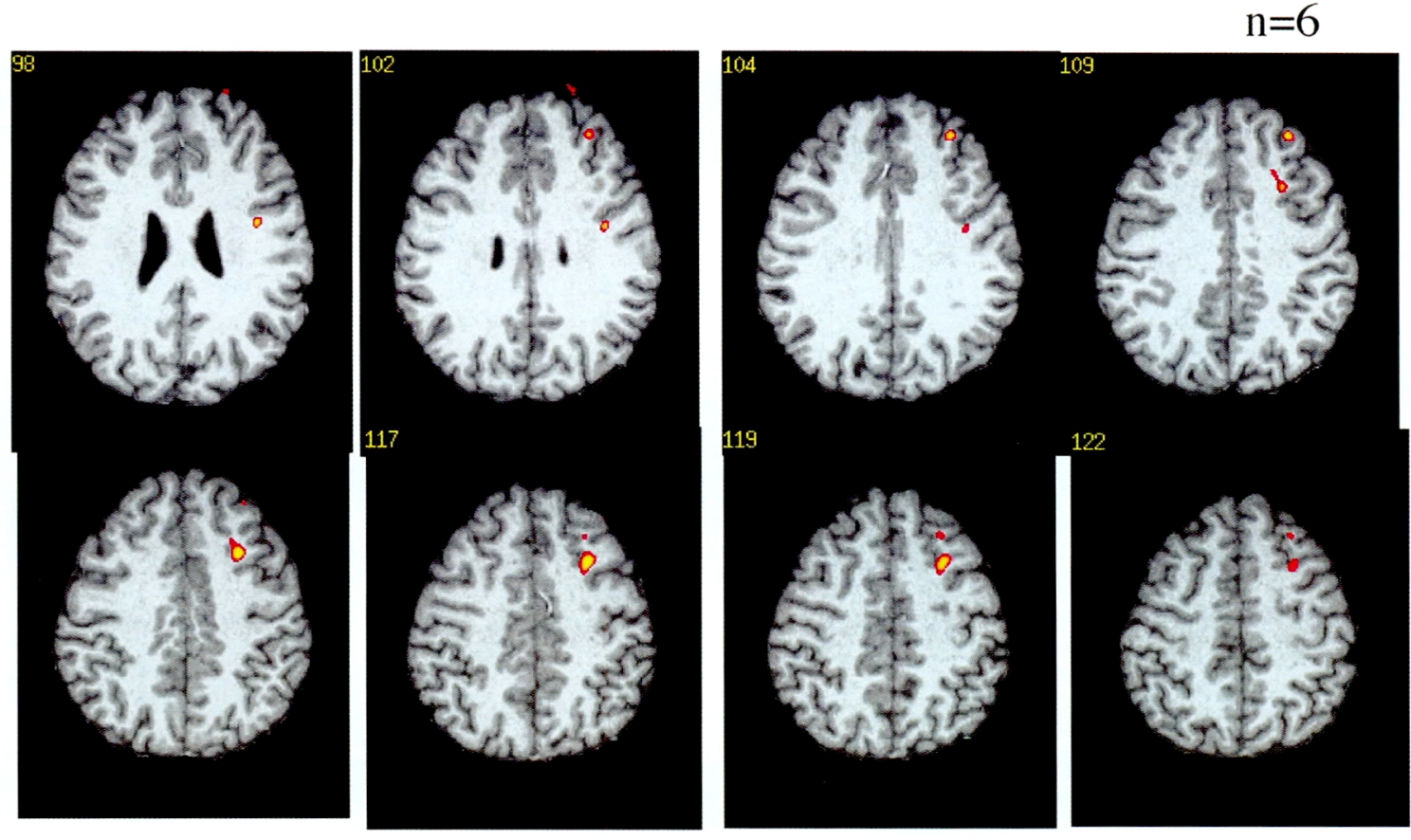

図7 温筒炎による脳機能画像 右合谷刺激時の代表的脳賦活領域を示している。 刺激右前頭葉に賦活部位が散在して認められた。 
温熱刺激では同側前頭葉の広範囲、尾状核、頭葉 にある二次感覚中枢などに賦活が見られた（図8）。 この温熱刺激の結果は、他の施設から報告されて いる結果と矛盾していないので、食刺激の fMRI も信頼性を有すると考えられた。しかし、众刺激 による賦活野が著しく温熱刺激よりも小さいので、 温筒众による刺激がfMRI で観察できる変化レベ ルと比べて少ない可能性がある。ところが、同時 に施行したAVSによる調査では、 $35^{\circ} \mathrm{C}$ 温熱刺激 と比べて、やや強い結果を得ている。ただし、今 回用いた刺激方法が温熱刺激では 60 秒間隔で 60 秒間の刺激を 4 回繰り返しているのに比べて、温 筒食の点火から消火までを 2 回用いる方法を用い たことによる少ない刺激量の可能性も考えられた。 今回の結果からは、fMRI を用いた鍼众刺激の脳 内処理過程の検討は、いまだ始まったばかりで、 今後すぐれたパラダイムの出現と、さらなる検討 に期待される。

\section{V.おわりに}

今回紹介できなかった多くの他のモダリティー を用いて、鍼众刺激の中枢への反応が調べられて いる。しかし、これらの研究はまだ始められたば かりであり、これからますます多くの成果が報告 されてくると考えられる。また、その成果を臨床 にフィードバックさせることでさらに臨床研究が 進むことを期待する。

このシンポジウムを企画し、いろいろと捣遣 い頂いた学会学術部に感謝致します。

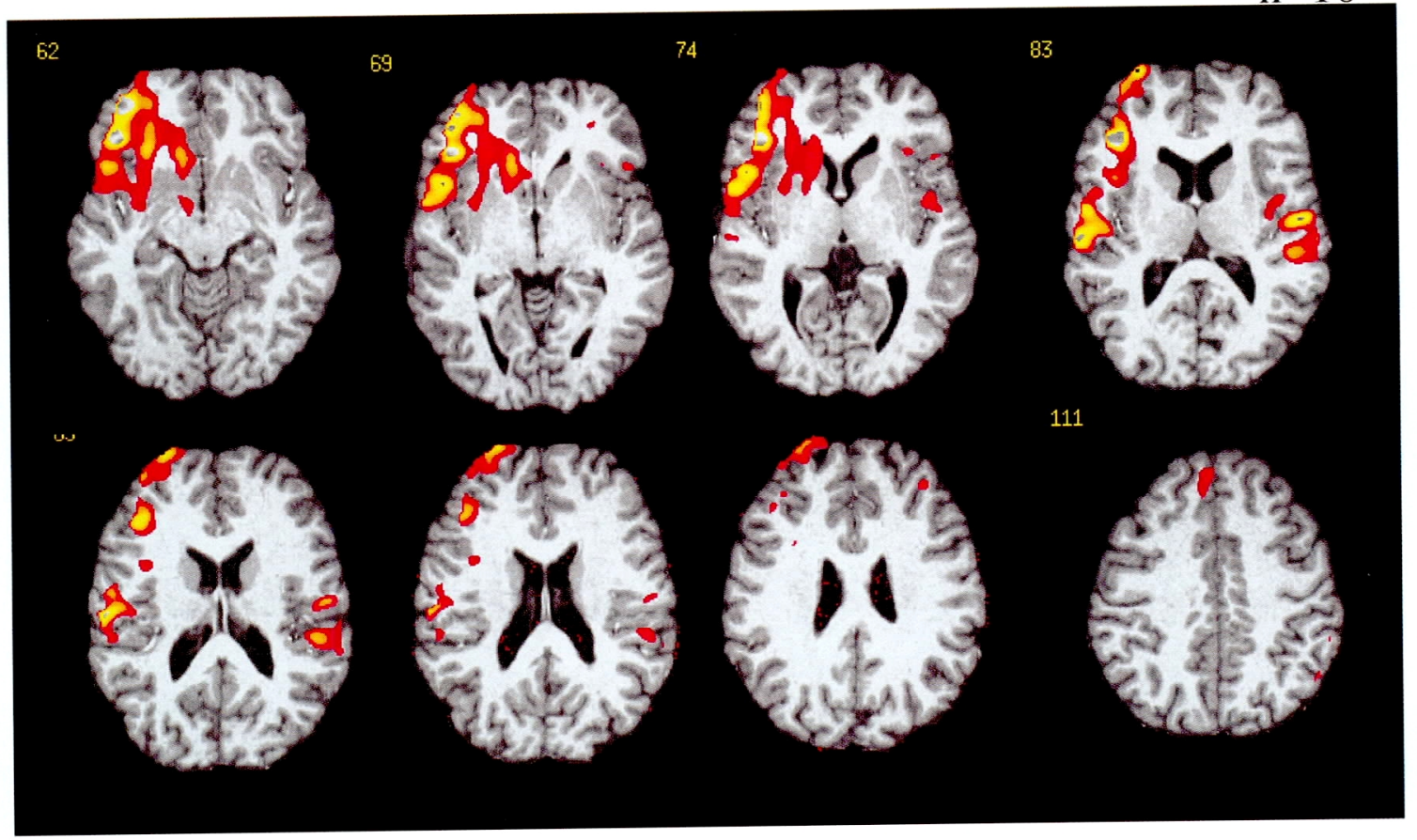

図 $835^{\circ} \mathrm{C}$ 温熱刺激の脳機能画像 右合谷刺激時の代表的脳賦活領域を示している。 緑上回 から島、外側前頭回、尾状核などに脳賦活が認められた。 
文 献

1) Hashimoto I, Mashiko T, Imada T. Somatic evoked high-frequency magnetic oscillations reflect activity of inhibitory interneurons in the human somatosensory cortex. Electroencephalogr Clin Neurophysiol. 1996; 100 (3) : 189-203.

2) Sakuma K, Hashimoto I. High-frequency magnetic oscillations evoked by posterior tibial nerve stimulation. Neuroreport. 1999; 10 (2) : 227-30.

3) Iguchi $Y$, Hoshi $Y$, Hashimoto I. Selective spatial attention induces short-term plasticity in human somatosensory cortex. Neuroreport. 2001; 12 (14) : 3133-6.

4) Kakigi R, Koyama S, Hoshiyama M, Kitamura Y, Shimojo M et al. Pain-related magnetic fields following painful $\mathrm{CO} 2$ laser stimulation in man. Neurosci Lett. 1995; 192 (1):45-8.

5) Ohtomo $S$, Nakasato N, Kawamura $T$, Kanno A, Seki $\mathrm{K}$ et al. Correspondence of anatomy and function in the human digit sensory cortex revealed by an MRI-linked whole-head MEG system. Electroencephalogr Clin Neurophysiol Suppl. 1996; 47: 91-5.

6) Kimura $T$, Hashimoto I. Source of somatosensory primary cortical evoked magnetic fields (N20m) elicited by index finger stimulation moves toward mediolateral direction in area $3 \mathrm{~b}$ in man. Neurosci Lett. 2001; 299: 61-4.
7) Hashimoto I, Kimura T, Sakuma K, Iguchi $Y$, Saito $\mathrm{Y}$ et al. Dynamic mediolateral activation of the pyramidal cell population in human somatosensory $3 \mathrm{~b}$ area can be visualized by magnetic recordings. Neurosci Lett. 2000; 280: 25-8.

8) Forss N, Hari R, Salmelin R, Ahonen A, Hamalainen $\mathrm{M}$ et al. Activation of the human posterior parietal cortex by median nerve stimulation. Exp Brain Res. 1994; 99 (2) : 309-15.

9) Inui K, Tran TD, Qiu Y, Wang X, Hoshiyama M, Kakigi R. A comparative magnetoencephalographic study of cortical activations evoked by noxious and innocuous somatosensory stimulations. Neuroscience. 2003; 120 (1): 235-48.

10）木村友昭, 西條一止, 橋本勲. 絶縁鍼通電刺激 による体性感覚誘発反応一脳磁図 (MEG) に よる検討一. 全日鍼尒会誌. 1998; 48 (1) : 55.

11）木村友昭, 西條一止, 橋本勲. Motor point 刺激 による脳磁場反応の信号源推定. 臨床脳波. 2000; 41 (9): 575-8.

12) Hui KKS, Liu J. Kwong KK. Functional mapping of the human brain during acpuncture with magnetic resonance imaging somatosensory cortex activation. World J Acup-Mox. 1997; 7: 44-9.

13) Wu MT, Hsieh JC, Xiong J et al. Central nervous pathway for acupuncture stimulation: Localization of processing of the brain-preliminary experience. Radiology. 1999; 212: 133-41.

14) Cho $\mathrm{ZH}$, Chung SC, Jones JP et al. New findings of the correlation between acupoints and corresponding brain cortices using functional MRI. Proc Natl Acad Sci USA. 1998; 95: 2670-3. 
THE 53 rd ANNUAL MEETING (CHIBA)

\title{
Symposium III
}

\section{"Brain Activation Study by Acupuncture"}

\author{
UMEDA Masahiro ${ }^{1)}$, SHIMOYAMA Ichiro $^{2)}$ \\ KIMURA Tomoaki' ${ }^{3)}$, TANAKA Chuzo ${ }^{4)}$
}

1) Department of Medical Informatics, Meiji University of Oriental Medicine

2) Reserch Center for Frontier Medical Engineering

3) Tsukuba College of Technology

4) Department of Neurosurgery, Meiji University of Oriental Medicine

\section{Abstract}

In this paper we introduce recent developments in the studies of brain activation during somatosensory stimulation exploiting new technologies. Somatosensory stimulation such as acupuncture, induces focal activation in the central nervous system. The electroencephalogram is a popular method to investigate this activation, however, it is difficult to identify the exact location of the activation site. Recent new technologies may provide more accurate localization. Besides magnetoencephalography (MEG), which recognizes the activated brain areas by an evoked magnetic field with induced current, two other methodologies, which take advantage of physiological phenomena occurring during brain activation, were used in this functional study. Following excitation of neurons, brain tissue is supplied with oxygen from oxyhemoglobin causing oxyhemoglobin to turn into deoxyhemoglobin. As a consequence deoxyhemoglobin increases in the brain tissue. In the near-infrared spectrum, the deoxyhemoglobin absorption peak shows higher signal intensity than that of oxyhemoglobin, for which reason activated brain areas can be identified by absorption maps. In functional magnetic resonance imaging (fMRI) activated area can be revealed with high spatial resolution due to the change in magnetic susceptibility of deoxygeneated blood. This paper describes fMRI studies employing these three methods for the evaluation of experiments using acupuncture for focal brain activation.

Zen Nippon Shinkyu Gakkai Zasshi (Journal of the Japan Society of Acupuncture and Moxibustion: JJSAM). 2004; 54(5): 686-697

Key words: brain function, acupuncture, near-infrared spectroscopy, MEG, fMRI 